\title{
2. INFLAÇÃO E RECESSÃo
}

PEREIRA, L.C.B. e NAKANO, Y. Inflação e Recessão. São Paulo, Brasiliense, 1984.

Um livro importante. Pela primeira vez, em língua portuguesa, uma sistematização das diversas teorias explicativas da inflação. Uma apresentação didática e original, que culmina na análise da "nova inflação", a inflação do "sistema monopolista" ou do "capitalismo tecnoburocrático".

Em aberto confronto com a "teoria quantitativa de moeda", os autores afirmam a possibilidade de autonomia das variações de preços frente à quantidade de moeda em circulação, com base no poder de mercado que hoje possuem os diversos agentes econômicos (principalmente os sindicatos e as empresas).

"Neste quadro, a inflação se transforma em um mecanismo de transferência de renda para os setores econômicamente mais fortes ou politicamente mais poderosos. (...) na medida em que os sindicatos se fortalecem (...), eles tenderão a exigir aumentos de salário acima do índice de preços mais o indice de produtividade. Neste momento, ante a ameaça às taxas de lucro (e na medida em que as empresas têm poder de mercado-MLM), estará também desencadeada a inflação." (pp. 30-31).

E com base na verificação deste "conflito constante e direto" que Bresser afirma que as expressões da "luta de classe(...) estão diretamente na base da inflação". (p.32). A partir desta constatação, a natureza e as funções do Estado passam a assumir papel determinante, tanto na sanção e impulso dos acréscimos de preços como na solução do processo inflacionário.

As divergências com a "teoria quantitativa da moeda", assim como as características do Estado, são os eixos norteadores da análise. Entretanto, é precisamente na teoria do dinheiro e na do Estado que situam-se os pontos fracos deste trabalho.

Com base na apresentação de dados empíricos, afirma-se que os "preços declinantes desapareceram do quadro histórico". (p.15, grifo-MLM). No entanto, em nenhum momento esta tendência histórica foi relacionada com as transfomações históricas do dinheiro, deixando transparecer que o dinheiro do período mercantilista ou dos primórdios do capitalismo e o de sua fase monopolista tem as mesmas características. As distinções entre o dinheiro metálico puro, o papel moeda conversível e o papel moeda não-conversível, parecem não jogar papel de relevância nas especificidades da "nova inflação", quando, na realidade, esta inflação característica do capitalismo monopolista, tem como fundamento uma elevação original do nível de preços sancionado pelo governo e pelo sistema bancário. 
"Diante da redução generalizada de liquidez (em função do aumento do nível de preços-MLM) e da iminência de crise, as autoridades monetárias serão obrigadas a emitir e também liberar o crédito, se o próprio sistema bancário não o fizer por sua própria conta". (p. 20).

É evidente que sob o domínio do dinheiro metálico puro ou do papel moeda conversível, o exercício destas práticas é impossível ou rapidamente neutralizado.

Assim, esta "tendência histórica" deve ser "relativizada, situando-a no pós segunda grande guerra e, principalmente, no perlodo que vai de 1971 até os nossos dias; perfodo no qual o dólar foi, de direito, desindexado do ouro. Embora nossos autores utilizem o perfodo indicado (pós $2^{a} \mathrm{GG}$ ) em seus quadros e estatísticas, fazem-no apenas considerando a nova estrutura monopolista do mercado e em total inobservância das características do dinheiro que permitem a especificada atuação das autoridades monetárias e do sistema bancário: o dinheiro poderia ser mera convenção néoclássica-monetarista ou o dinheiro-mercadoria de Marx, o que em nada'al teraria as conclusões de Bresser e Nakano/

Os reflexos desta concepção eclética do dinheiro podem ser melhor observados na indefinição sobre a natureza do Estado e, conseqüentemente, sobre as políticas econômicas por ele implementadas.

Explicitamente, credita-se ao Estado a "características fundamental de estar a serviço da acumulação capitalista" (p.32) ou, em outras palavras, de ser o

Estado do capital. De forma ainda mais incisiva, define-se o caráter do Estado e os limites de suas políticas econômicas, afirmando-se que "os controles do Estado não podem violentar a lei do valor". (p. 36). Entretanto, na página 35, como que "cercada" pelas duas declamaçôes de princípios acima citadas, aparece sorrateiramente, a concepção de Estado neutro e acima das classes, a qual permeia todo o texto: o Estado aparece como administrador de preços desinteressado, substituindo-se à lei do valor e considerando todos os agentes econômicos em igualdade de condições:

“Na verdade, o Estado, enquando administrador de preços, tem um papel todo especial. Geralmente sua função é segurar os preços, é substituir-se ao mercado (violentar a lei do valor, portanto-MLM) como única alternativa de controle de preços em uma economia dominada pelo sistema de planejamento. Esta administração de preços por parte do Estado é fundamentalmente uma administração de lucros, salários e ordenados. É, portanto, uma política de rendas. Ao administrar os preços das mercadorias, o Estado pretende controlar os lucros das empresas; ao controlar os salários, os lucros das empresas e os salários dos trabalhadores; ao controlar os juros, os lucros dos bancos e as rendas dos rentistas financeiros; ao cntrolar os aluguéis, as rendas dos rentistas imobiliários" (p. 35).

Assim, sem compromissos com nenhuma classe social - ou aliança de clas- 
ses - o Estado é o administrador da riqueza social, compromissado apenas com a sociedade em abstrato. Trata-se, sem dúvida, da concretização do "Estado tecnoburocrático", noção desenvolvida em outra obra de Bresser Pereira e de aplicabilidade tanto aos países capitalistas quanto aos que realizaram a revolucãa socialista.

Muitas outras questões polêmicas poderiam ser levantadas. Apenas como exemplo, poder-se-ia citar a necessidade de "legitimidade" do governo, reclamada por Bresser (p. 39), como condição necessária ao combate à inflação. Seria a legitimidade para melhor servir à "acumulação de capital"? Neste caso, a legitimidade seria fornecida pelos capitalistas, por uma minoria. Sem colocarmos em questão a validade desta "legitimidade", não há dúvidas que somente com base nela poder-se-ia afirmar que a "única forma coerente de contê-la (a inflação-MLM) é controlando os preços" (p. 128). Em nome de uma coerência integral ácrescentarfamos - com a permissão dos autores - "da força de trabalho".

Para terminar, duas características interessantes deste livro precisam ainda ser apontadas. Primeiro, o fato da obra ser composta por artigos assinados, permitindo ao leitor observar as divergências e sutis diferenças de concepçôes entre os do is autores. Isto tanto no que concerne à criatividade e ilustração do pensamento de Bresser Pereira quanto à tacanhez tecnocrática de Nakano. Por último, a impossibilidade de largarmos o tex to antes da última página ser virada. As contradições do trabalho, sua construção eclética e maleável, provocam uma interminável e rica série de reflexões sobre a temática estudada.

Manoel Luiz Malaguti 